\title{
Social Network Analysis: Literature Review
}

Nursen AYDIN, Dr., Hatay Provincial Health Directorate, Hatay, Turkey, nursen.aydin@saglik.gov.tr

ABSTRACT In this article, social network analysis (SNA) is defined and historical development process is explained. A comprehensive literature search has been conducted for this purpose. SAA is a powerful method that centralizes individuals and their relations, in that the effect of the individual on the social network can be uncovered and the network of individual groups can be evaluated holistically. SNA shows the structural gaps and social capital in institutions, and focuses managers' attention on critical informal networks. Evaluating strategically important networks within an organization, make "invisible" groups visible in the interaction and allows them to work with key groups to facilitate effective collaboration.

Keywords: Social Network Analysis, Health, Research Methods.

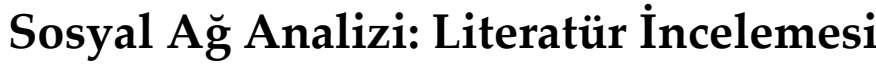

öz

\begin{abstract}
Bu makalede sosyal ăg analizi tanımı yapılarak sosyal ă̆ analizinin (SNA) tarihsel gelişim süreci açılanması amaçlanmıştır. Bu amaçla kapsamlı literatür taraması yapılmıştır. SAA, bireylerin sosyal ağdaki etkisinin ortaya çıkarılması ve birey gruplarının oluşturduğu ă̆̆n bütünsel olarak değerlendirilebilmesinde, kişileri ve ilişkilerini merkeze alan güçlü bir yöntemdir. Sosyal ă̆ analizi kurumlardaki yapısal boşluklar ve sosyal sermayeyi göstermekte, yöneticilerin dikkatini kritik informal ağlara odaklamaktadır. Bir organizasyon içindeki stratejik olarak önemli ağlar değerlendirmek, etkileşim halindeki "görünmez" grupları görünür hale getirmek ve etkili işbirliğini kolaylaştırmak için önemli gruplarla çalışma imkânı sağlar.
\end{abstract}

Anahtar Kelimeler: Sosyal Ağ Analizi, Sağlık, Araştırma Yöntemleri.

\section{INTRODUCTION}

Social events and cases are the result of people's activities and social research should be based on the human factor. Traditional statistical research methods are often criticized on the grounds that they can not reveal the true cause of human social behaviour. SAA is a tool that removes the lack of traditional statistical research methods in social sciences and helps to analyse human behaviours and relationships.

The SAA examines the structure of social relations in a group, mostly in the form of communication, consciousness, trust and decision-making. It reveals informal connections between people (Ehrlich \& Carboni, 2005). Relations of individuals, institutions or businesses, friendship, cooperation, trade, information, communication, etc. are called social network. Friendship, cooperation, trade, information, communication, etc. any kind of relationships or connections of individuals, institutions or businesses are called social 
networks. The biggest difference between traditional researches and social network analysis is that, focusing on the relationships of actors in network analysis while focusing on actors and qualities in traditional researches. In network analysis, individuals and their qualifications are not take in to consideration (Hanneman \& Riddle, 2005).

SAA is mainly focused on the structure of relations. By examining the formal and informal relations through analysis the following information can be reached such as what increases or decreases the flow of information and information between the parties, who knows whom, whom and who shares information and knowledge. In the SAA, measures of specific statistics have been developed, such as centrality and intensity, which provided interdependence measures. Thus, rather than individual-centered perspective, the possibility of examining the whole network (the effect of the entire individuals) arises.

This study was conducted with a systematic review of six online databases, including Since Direct, Google Scholar, Academic Search Complete, Access Medicine, Cambridge Journals Online and Medline. The SAA's historical development process will be explained below.

\section{Development of Social Network Analysis}

The history of social networks goes back to the first years of humanity. Since the time people have helped with others, it has existed, even if it has been mostly invisible. In the development of social network analysis, theories such as social change theory and network theory have become effective. According to the theory of social change, social behaviour is based on the exchange of goods, including intangible goods such as approval or prestige symbols, as well as the exchange of corporeal goods (Emma, 2013).

Many researchers including Homans (1958), Blau (1964) and Emerson (1976) have contributed to the development of social change theory (Blau, 1964; Emerson, 1976; Homans, 1958). Relations with network theory and structural analysis have been associated with each other and have begun to be studied in areas such as sociology, social psychology, and anthropology. In order to visualize interpersonal connections with sociometry, people are expressed as dots and the connections are also represented as the line between the dots. This representation is often called sociogram (Wasserman \& Faust, 1994).

It is generally accepted that Jacob Moreno is the founder of sociometry (Carrington, 2014; Freeman, 1996). Moreno laid the foundations of sociometry in his 1934 book "Who Shall Survive". This basis usually consists of a number of researches which are made up of various communities (Moreno, 1978). Modern social network analysis was first introduced by Moreno and Jennings (1938) (Moreno \& Jennings, 1938). Moreno and Jennings have proposed network theory with the study of interpersonal relationships and have laid the foundations of sociometry by visualizing interpersonal connections. The results of the study indicated that universally skewed distributions were observed and the expectations based on random selections differed. In the 1940s, Warner worked on social networks. The foundations of this work are based on research conducted by the Western Electric Company at the Hawthorne Factory in the 1920s. As a result of the research, it has been found that the 
physical and financial environment improvements do not increase productivity much more than dealing with the employee, organization members do not like the competition within the groups they belong to, and they refrain from group pressure (Kocel, 2013; Sonnenfeld, 1985). Therefore, the second step of the study called as "Bank Cabling Room" was conducted in order to examine the social effects (Roethlisberger \& Dickson, 1939; Smith, 1986).

In 1938, Lewin investigated the subject of "Democracy" and "Autocracy" in the society in social psychology field (Billig, 2015). In 1941 Warner and Lunt (1941) conducted the study related to the imitation relation in the family, and Davis et al. (1941) researched on the daily life of the Mississippi community (Warner \& Lunt, 1941; Davis, Gardner, \& Gardner, 2009). Festinger and colleagues (1950) studied social pressures in society (Festinger, Schachter \& Back, 1950). Leavitt (1951) investigated the effects of four different forms of communication on the task performance of small groups and the behaviour of individual members of these groups (Leavitt, 1951). The study was conducted in order to determine the network of communication channels that connect the group members with each other through communication pattern, the model is analysed holistically and spatially, and the centrality degrees of the relationships in the analysis are measured.

At the end of the 1970s, social network analysis was universally accepted among social scientists (Freeman, 2011). During this period, Harrison C. White has had many influential studies on social network analysis. White examined graphics, the social structure in multiple networks, and block models of the roles and positions of social groups in his three distinct articles (White \& Heil, 1976; White \& Boorman, 1976; White, Boorman \& Breiger, 1976). Pool and Kochen (1978) in the study with regard to acquaintances who connect couples, it was found that couples were linked to an acquaintance chain with a tool of no more than seven people (Pool \& Kochen, 1978). The data obtained in the study were explained by the graph theory model.

At the end of the 1990s, there have been radical changes in the field of social networking. In Watts and Strogatz's (1998) "Small-World Networks" titled article, alertable media, neural networks, infectious disease networks, genetic control networks, and many other selfregulating system networks are described and modeled as social networks system (Watts \& Strogatz, 1998). In the study, the distance between the two corners (general feature) and the clicks of the typical neighborhood (local feature) were measured with the characteristic path length $L(p)$ and the clustering coefficient $C(p)$. Over time, the research on small worlds has gained widespread and diversity amongst many disciplines and research topics thus, the whole has been noticed (Burke, 2003). In the work of Barabasi and Albert (1999), they showed a random (scaled) network model and examined the distribution of degree centers and the cluster items (Barabasi \& Albert, 1999). Similar to the results of Moreno and Jennings, the study showed that there were several nodes with too many connections, a large number of nodes with very few connections, a distribution of links that tracked the power law, or that there was no certain scale. In the research of Moody and White (2003) on social cohesion and social embeddedness, the concept of structural cohesion based on network node connectivity has been developed and it has been advocated that social cohesion can be divided into analytically intellectual and relational components (Moody \& White, 2003). 
Otte and Rousseau (2002) reviewed the studies in the field of sociology, medicine, and physical sciences through social network analysis (Otte \& Rousseau, 2002). They analysed the articles from the databases, implemented the linear regression on the social network data and displayed them graphically based on time factor. Cross et al. (2002) conducted a study in a firm where they believed that the firm management did not use the strategically important team's talents as efficiently as possible (Cross, Borgatti \& Parker, 2002). In the first analysis, they determined that the team had two subgroups and that there was a conflict between these subgroups. On this basis, the management of the firm evaluated the situation and a set of interventions were carried out such as determination of common goals, enhancing collaboration etc. The group was found to be an integrated group that shares information more efficiently and more successful than before by combining technical and organizational skills according to the social network analysis that was done nine months later. This research is important for showing the successful implementation of social network analysis in corporate governance.

Killworth et al. (2003) investigated how many subpopulations the participants knew and explained the results graphically (Killworth et al., 2003). In another study by Killworth et al. (2006), they analysed the connections that individuals use in their selection of agents in the examination bureau and calculated the small world path length (Killworth, McCarty, Bernard \& House, 2006). It is revealed that the average small world path length (3.23) is $40 \%$ longer than the average of the average of the real shortest paths (2.30) and that more than half of the people making small world selection wrong. Daly and Haahr (2007) conducted a social network analysis to characterize the mobilization and distribution of mobile networks (Daly \& Haahr, 2007). Centrality and similarity criteria were examined in this analysis.

Hoppe and Reinelt (2010) describe how to use social network analysis to assess the impact of leadership development on leadership networks by framing leadership networks in the article they have prepared to evaluate leadership networks in the context of social network analysis (Hoppe \& Reinelt, 2010). Leadership network structures that explain leadership styles in different sectors and organizations are illustrated by social network graphics. Demir and Taktak (2011) conducted a research on public institutions, private sector, local governments, and other sectors that use spatial data and services, in order to reveal the communication network between them (Demir \& Taktak, 2011). Network density, social network centrality, proximity, betweenness (out-degree, in-degree, in-closeness, outcloseness, betweenness) and the network's basic measurement values (ego networks) are calculated based on the actors. A dendogram was created by hierarchical clustering method in the study. The institutions that need more spatial data are getting closer to the network center, while those with less interest in spatial data are getting away from the network center, according to the results of the study.

Gulpinar (2013) worked on estimating the customer loss in the Turkish telecommunication market with artificial neural networks and analysing the customer communication network with the help of social network analysis in order to examine the positions and effects of the customers who are at risk of loss on the network (Gulpinar, 2013). In the study, important nodes in the social network were identified, and the network density, social network centrality, proximity and betweenness measures were calculated based on the 
actors. As a result of the research, it has been concluded that the characteristics of the individuals are important, but not enough alone, in determining the loss of customers. Amabile et al. (2014) conducted a research on cooperation in a design firm called IDEO (Amabile, Fisher \& Pillemer, 2014). As a result of the research, it has been shown that the help was asked from the most reliable and accessible staff instead of asking to technically competent staff, and the successful cooperation experience increased morale and job satisfaction.

Kahraman and Sevim (2014) have conducted research in order to test the gravity model through social network analysis by taking into consideration international economics as consists all the countries of the world (Kahraman \& Sevim, 2014). Centrality (out-degree) values, cliques in the network setup (subgroup-clique), and co-membership values were tested from the data obtained by the study. As a result of the research, it is seen that the countries that are the most exporting countries are not only allied by the countries that are geographically close to them, but also the ones that far from them in terms of direct and indirect relations. In accordance with the gravity model, despite the decrease in foreign trade is expected while distance increases, it is seen that distance factor does not affect the foreign trade negatively for the countries that are leading the world trade.

Sociology, physics sciences as well as health sciences social network analysis studies have been done. Provan and Sebastian (1998), in their study of three different healthcare providers, they conduct a clique analysis to explain the network activity that they got through the questionnaire and interview (Provan \& Sebastian, 1998). In the framework of the analysis, they measured the size of cliques, dyadic links, and network density, and graphically displayed the results. Behrendt et al. (2014) conducted research on the institutional social networks of health workers and Perkins et al. (2015) on natural social networks in low and middle-income countries (Behrendt, Richter \& Trier, 2014; Perkins, Subramanian \& Christakis, 2015). Aydin and Bekâroğlu (2017) conducted research that determined the help relationship among the employees of three public health institutions in Istanbul (Aydin \& Bekâroglu, 2017). In the framework of the research, the health institutions measured the network density of the help relations and graphically displayed the helping maps of the institutions.

SAA in the field of health; how the disease spreads, identification of the source of the epidemic, demonstration of the relations of scientific research groups, information flow among employees, help relationships, etc. in issues are widely used by many companies, universities, institutions and organizations.

\section{CONCLUSION}

The employees in the institutions are part of the invisible social networks that exist in those institutions. SAA is considered to be a powerful method for uncovering the effects of social networking on employees in the institutions and for evaluating the network of 
employees' groups as a whole. Through SAA analysis, relationships between individuals can be revealed, data about social relations can be collected and analysed.

When you look at social network analysis from the point of view of management science, it is a tool that allows to study strategically important networks within an organization, to recognize informal groups and to work with important groups to facilitate effective collaboration. Perhaps the most important benefit of social network analysis is that managers focus their attention on informal networks that can be critical to organizational effectiveness (Cross, Borgatti \& Parker, 2002).

It is mostly informal relations in that organization that characterize an organization and influence the organization. One of the important ways using which managers can accept what all members of the organization want to do, is to influence informal groups. To achieve this they need to know the types of relationships in the organization and their interactions, existing groups, leaders and how they can react (Onal, 2004). SNA shows the structural gaps and social capital in institutions, and focuses managers' attention on critical informal networks. The properties that indicate the informal structure (such as groupings in the organization, isolated person or groups, and broker employees) of the organization can be identified through SAA and network maps can be shown. If health managers taking into account what has emerged in these mappings (subgroups, broker actors, density, etc.) it may be useful for the policy-making and for the purposes of their organization.

\section{REFERENCES}

Amabile, T., Fisher, C. M., \& Pillemer, J. (2014). IDEO's culture of helping. Harvard Business Review, Harvard Business School Publishing Corporation. January-February, 1-9.

Aydin, N, \& Bekâroglu, Ş. B. (2017). A social network analysis on the culture of helping in health institutions. Journal of Global Strategic Management, 11 (2), 033-050.

Barabasi, A. L., \& Albert, R. (1999). Emergence of scaling in random networks. Science, 286, 509-512.

Behrendt, S., Richter, A., \& Trier, M. (2014). Mixed methods analysis of enterprise social networks. Computer Networks, 75, 560-577.

Billig, M. (2015). Kurt Lewin's leadership studies and his legacy to social psychology, is there nothing as practical as a good theory? Journal for the Theory of Social Behaviour, 45 (4), 440-460.

Blau, P. M. (1964). Exchange and power in social life. New York: John Wiley and Sons, Transaction Books.

Carrington, P. J. (2014). Early research in social networks. In: S. Dominguez, \& B. Hollstein (eds.), Mixed Methods Social Networks Research, Design and Applications (pp. 3839). New York: Cambridge University Press.

Cross, R., Borgatti, S. P., \& Parker, A. (2002). Making invisible work visible, Using social network analysis to support strategic collaboration. California Management Review, 44 (2), 25-46.

Daly, E., \& Haahr, M. (2007). Social network analysis for routing in disconnected delaytolerant MANETs. MobiHoc, 9 (1), 32-40. 
Davis, A., Gardner, B. B., \& Gardner, M. R. (2009). Deep South. Chicago: The University of Chicago Press.

Demir, H., \& Taktak, F. (2011). Social network analysis on spatial data (SNA), Afyonkarahisar example. Electronic Journal of Map Technologies, 3 (1), 7-16.

Ehrlich, K., \& Carboni, I. (2005). Inside social network analysis. Boston College, 1-13.

Emerson, R. M. (1976). Social exchange theory. Annual Review of Sociology, 2 (1), 335-362.

Emma, C. (2013). Sociological theory in the contemporary era: Exchange and rational choice theories: Peter M. Blau (1918-2002): A biographical sketch. 136-153.

Festinger, L., Schachter, S., \& Back, K. (1950). Social pressures in informal groups. New York: Harper and Bros.

Freeman, L. C. (1996). Some antecedents of social network analysis. Connections. 19 (1), 39-42.

Freeman, L. C. (2011). The development of social network analysis, With an emphasis on recent events. http,//moreno.ss.uci.edu/91.pdf

Gulpinar, V. (2013). Customer loss analysis in Turkish telecommunication market with artificial neural networks and social network analysis assistance. Marmara University Journal of Economics and Administrative Sciences, 34 (1), 331-350.

Hanneman, R. A., \& Riddle, M. (2005). Introduction to social network methods. Riverside, CA: University of California, Riverside.

Homans, G. C. (1958). Social behavior as exchange. American Journal of Sociology, 63 (6), 597606.

Hoppe, B., \& Reinelt, C. (2010). Social network analysis and the evaluation of leadership networks. The Leadership Quarterly, 21, 600-619.

Kahraman, Ç. A., \& Sevim, C. (2014). Dış ticarette doğrudan ikili ilişkilerden öteye dolaylı ilişkiler belirlenebilir mi? A $\breve{g}$ analizi yaklaşımı ile çekim modelinin testi. Sosyal Bilimler Enstitüsü Dergisi, 4 (1), 41-58.

Killworth, P. D., McCarty, C., Bernard, H. R., Johnsen, E. C., Domini, J., \& Shelley, G. A. (2003). Two interpretations of reports of knowledge of subpopulation sizes. Social Networks, 25, 141-160.

Killworth, P. D., McCarty, C., Bernard, H. R., \& House, M. (2006). The accuracy of small world chains in social networks. Social Networks, 28, 85-96.

Kocel, T. (2013). Business administration (12rd ed.). Istanbul: Beta Publications.

Leavitt, H, J. (1951). Some effects of communication patterns on group performance. Journal of Abnormal and Social Psychology, 46, 38-50.

Moody, J., \& White, D. R. (2003). Structural cohesion and embeddedness, a hierarchical concept of social groups. American Sociological Review, 68 (1), 103-127.

Moreno, J. L. (1978). Who shall survive? Foundations of sociometry, group psychotherapy and sociodrama (3rd ed.). New York: Beacon, NY, Beacon House.

Moreno, J. L., \& Jennings, H. H. (1938). Statistics of social configurations. Sociometry, 1, 342374.

Onal, G. (2004). Business administration and organization (3rd ed). Istanbul: Turkmen Bookstore. 
Otte, E., \& Rousseau, R. (2002). Social network analysis, a powerful strategy, also for the information sciences. Journal of Information Science, 28 (6), 441-453.

Perkins, J. M., Subramanian, S. V., \& Christakis, N. A. (2015). Social networks and health, A systematic review of sociocentric network studies in -low and middle- income countries. Social Science and Medicine, 125, 60-78.

Pool, I. D., \& Kochen, M. (1978). Contacts and influence. Social Networks, 1 (1), 5-51.

Provan, K. G., \& Sebastian, J. G. (1998). Networks within networks, Service link overlap, organizational cliques, and network effectiveness. The Academy of Management Journal, 41 (4), 453-463.

Roethlisberger, F. J., \& Dickson, W. J. (1939). Management and the worker. Cambridge: Harvard University Press.

Smith, J. H. (1986). Elton Mayo and the hidden Hawthorne. Work, Employment \& Society, 1 (1), 107-120.

Sonnenfeld, J. A. (1985). Shedding light on the Hawthorne studies. Journal of Occupational Behaviour. 6 (2), 111-130.

Warner, W. L., \& Lunt, P. S. (1941). The social life of a modern community. New Haven: Yale University Press.

Wasserman, S., \& Faust, K. (1994). Social network analysis, Methods and applications. Cambridge University Press.

Watts, D. J., \& Strogatz, S. H. (1998). Collective dynamics of small-world networks. Nature, 393 (6684), 440-442.

White, H. C., \& Heil, G. H. (1976). An algorithm for finding simultaneous homomorphic correspondences between graphs and their image graphs. Behavioral Science, 21, 2635.

White, H. C., Boorman, S. A., \& Breiger, R. L. (1976). Social structure from multiple networks, Part I. blockmodels of roles and positions. American Journal of Sociology, 81, 730-780.

White, H. C., \& Boorman, S. A. (1976). Social structure from multiple networks, Part II. role Structures. American Journal of Sociology, 81, 1384-1446. 